\title{
Metabolic Syndrome among Indigenous People (Orang Asli) in Peninsular Malaysia: A Systematic Review
}

\author{
Muslimah Ithnin ${ }^{1}$, Khairun Nain Nor Aripin², Nadia Mohd Effendy², Norsham Juliana ${ }^{3}$, \\ Nadeeya 'Ayn Umaisara Mohamad Nor ${ }^{1}$ and Mohd Dzulkhairi Mohd Rani1 ${ }^{*}$ \\ ${ }^{1}$ Department of Primary Care, Faculty of Medicine and Health Sciences, Universiti Sains \\ Islam Malaysia, Kuala Lumpur, Malaysia \\ ${ }^{2}$ Department of Medical Science II, Faculty of Medicine and Health Sciences, Universiti \\ Sains Islam Malaysia, Kuala Lumpur, Malaysia \\ ${ }^{3}$ Department of Medical Science I, Faculty of Medicine and Health Sciences, Universiti Sains \\ Islam Malaysia, Kuala Lumpur, Malaysia
}

\begin{abstract}
Metabolic syndrome is a cluster of conditions that increase the risk of developing chronic diseases. This paper aims to assess the data on metabolic syndrome among indigenous Orang Asli in Malaysia. Searches were carried out using electronic databases of CINAHL, Medline, PubMed, and Scopus using predefined keywords. Cross-sectional studies of metabolic syndrome using any clinical diagnosis criteria among adult Orang Asli in Peninsular Malaysia included. Fifteen studies with these criteria were selected, five with metabolic syndrome studies. The general prevalence (weighted mean) of metabolic syndrome in Orang Asli was 26.3\% (range: 12.0-39.8). Metabolic syndrome was more frequent in females (30.0\%) than in males (19.3\%). The most common components of metabolic syndrome were low HDL-C levels (41.0\%) and hypertension (33.7\%). For abdominal obesity, high triglycerides, and abnormal glycemia, the prevalence was; $24.6 \%, 21.5 \%$, and $14.0 \%$, respectively. Conclusively, the present systematic review brings us closer to an understanding of the prevalence of metabolic syndrome among this vulnerable population. The methodological differences among the studies published limit a joint analysis of their results. Nevertheless, finding from this review shows their high prevalence of the metabolic syndrome is comparable with other ethnic groups in Malaysia that requires immediate attention from all related parties.
\end{abstract}

Keywords: indigenous; orang asli; adult; Malaysia; metabolic syndrome;

prevalence

\section{INTRODUCTION}

Metabolic syndrome is a cluster of risk factors that occur together, which increases the risk of developing heart diseases, stroke, and type 2 diabetes mellitus (Cornier et al., 2008). The risk factors include increased blood pressure, high blood sugar, abdominal obesity, and abnormal triglyceride, or high-density lipoprotein cholesterol levels (Alberti et al., 2005).
According to the findings of a systematic analysis for the Global Burden of Disease Study 2015 by Forouzanfar et al. (2016), a large body of epidemic studies has demonstrated that metabolic risks contribute significantly to preventable chronic NCDs morbidity and mortality. For analysis based on country, the major risk factors in terms of disability-adjusted life-years (DALYs) for both sexes combined in 2015 for Malaysia are; increased blood pressure, increased fasting plasma glucose, high body mass index and high total 
cholesterol. Increased prevalence of metabolic syndrome reflects the behavioural risk factor of an unbalanced diet and sedentary lifestyles in the populations (Institute for Public Health Malaysia, 2015; Lim and Cheah, 2016).

Malaysia is a multi-ethnic heterogeneous population consisting of major ethnic of Malays (51\%), Chinese (27\%), Indians (8\%), and mixed ethnic groups, including indigenous groups (14\%). In Peninsular (West) Malaysia, $0.5 \%$ of the population comprises of the minority indigenous people of Orang Asli (Department of Statistics Malaysia, 2000). There are large tribes and smaller subtribes that are categorised based on their physical characteristics, cultural practices, and linguistics. The three large tribes are the Negrito in the northern region, the Senoi in the central area, and the ProtoMalay in the southern part of Peninsular Malaysia (Endicott, 2015).

The Government of Malaysia has put up continuous effort to bring modernisation to the Orang Asli through the Department of Orang Asli Development (JAKOA) of Malaysia. This modernisation has shifted the epidemiological trend of diseases among the Orang Asli, particularly the Orang Asli, at the peripheries of townships. They have adopted modern life with a more sedentary lifestyle and a change in diet. Even though the studies among this population is limited, previous surveys of metabolic syndrome focused on specific groups of Orang Asli shows that their prevalence is comparable with Malaysian general populations (Aziz et al., 2015; Aghakhanian et al., 2018).

The Orang Asli was reported to have a low health status, low socioeconomic status, and they are lagging in terms of education (Masron et al., 2013). Increased prevalence of metabolic syndrome marks high utilisation and costs of medical care not only to the individuals who are affected but also to their family and the government (Boudreau et al., 2009). Hypothetically, continuous adaptation to an urbanised lifestyle leads to an increased burden of metabolic syndrome among the Orang Asli. Analysing available data on these minorities is essential to provide a snapshot of their state of health. This data will give a real prevalence of this syndrome among the Orang Asli population.

Therefore, the objective of the present systematic review is to assess the prevalence of metabolic syndrome and its criteria in the Orang Asli using data published in scientific works of literature.

\section{METHODS}

\section{A. Source and Search Strategy}

Searches were conducted using electronic databases of CINAHL, Medline, PubMed and Scopus. These electronic databases were assessed until 12 September 2019. Additional studies also identified by retrieval from the reference list of selected articles.

\section{B. Keyword Search}

These terms were searched in full text:

- [metabolic syndrome OR syndrome X OR metabolic syndrome X];

- [Orang Asli OR indigenous OR native OR aboriginal OR original OR proto-Malay OR Senoi OR negrito]; and

- Malaysia

\section{Selection of Research Article/Inclusion and Exclusion Criteria}

Eligible studies: 1) were observational studies; 2) stratified participants based on the presence or absence of the metabolic syndrome criteria using any metabolic syndrome definitions; 3) were conducted among any Orang Asli population; 4) reported outcomes as count data, or prevalence and 5) were published in the English and Malay language.

Studies investigating more than one metabolic syndrome, or more than one definition of the metabolic syndrome were also eligible for inclusion. Studies not meeting these criteria were excluded.

Criteria for in- or excluding retrieved articles formulated based on the discussion of the research team members. The criteria tested on two batches at the title and abstract and also the full-text level of twenty articles regarding their relevance, as well as understandability and practicality to eliminate the bias in study selection.

Two reviewers (MI and NME) independently screened each title and abstract, which categorised as include, exclude, or 
unsure. The titles and abstracts were compared and then categorised again following a consensus discussion if the two reviewers disagreed. When there was an agreement to exclude, the citation excluded at this stage. Articles with an agreement to include or as unsure were reviewed by reading the full text. Studies considered as unsure after reading the full text reviewed by a third reviewer (KNNA). Reasons for exclusion documented at the full-text stage of the screening process.

\section{Data Extraction and Management}

Two reviewers independently extracted data using standardised data extraction forms. Disagreements were resolved by consensus or, when necessary, by a third reviewer. Reviewers extracted information on author and year of publication, year of conducted study, number and gender of participants, the age range of the population, sampling, tribe of the Orang Asli, the city in which the study was carried out and procedures to determine metabolic syndrome and its components (measurements) as well as the prevalence of metabolic syndrome and its components.

The (weighted) mean prevalence rates found in the present review were calculated as follows: the sum of the number of cases in all studies considered/sum of the number of participants in all studies considered x 100.

\section{RESULT}

As shown in the flow diagram (Figure 1), 160 articles were initially identified using the keywords. Ten additional records found through other sources. After duplicate records removed, 167 records were screened based on inclusion and exclusion criteria. Fifteen articles were finally chosen to be reviewed and summarised in Table 1.

\section{A. Prevalence of Metabolic Syndrome}

The five studies included in this section encompassed 1196 Orang Asli published from 2016 to 2019 (Table 1). In these five studies, the general prevalence of metabolic syndrome (Ali et al., 2016; Ashari et al., 2016; Aghakhanian et al., 2018; Mokhsin et al., 2018; Zahary et al., 2019) was reported. In these studies that mentioned rates of prevalence, the weighted mean for metabolic syndrome general prevalence was $26.3 \%$.

Three studies (Ali et al., 2016; Ashari et al., 2016; Aghakhanian et al., 2018) used Joint Interim Statement's (Alberti et al., 2009) definition as a measure of metabolic syndrome, whereas Mokhsin et al. (2018) used International Diabetes Federation's (Alberti et al., 2006) definition. Another recent study by Zahary et al. (2019) used a modified National Cholesterol Education Program High Blood Cholesterol ATP III metabolic syndrome criterion.

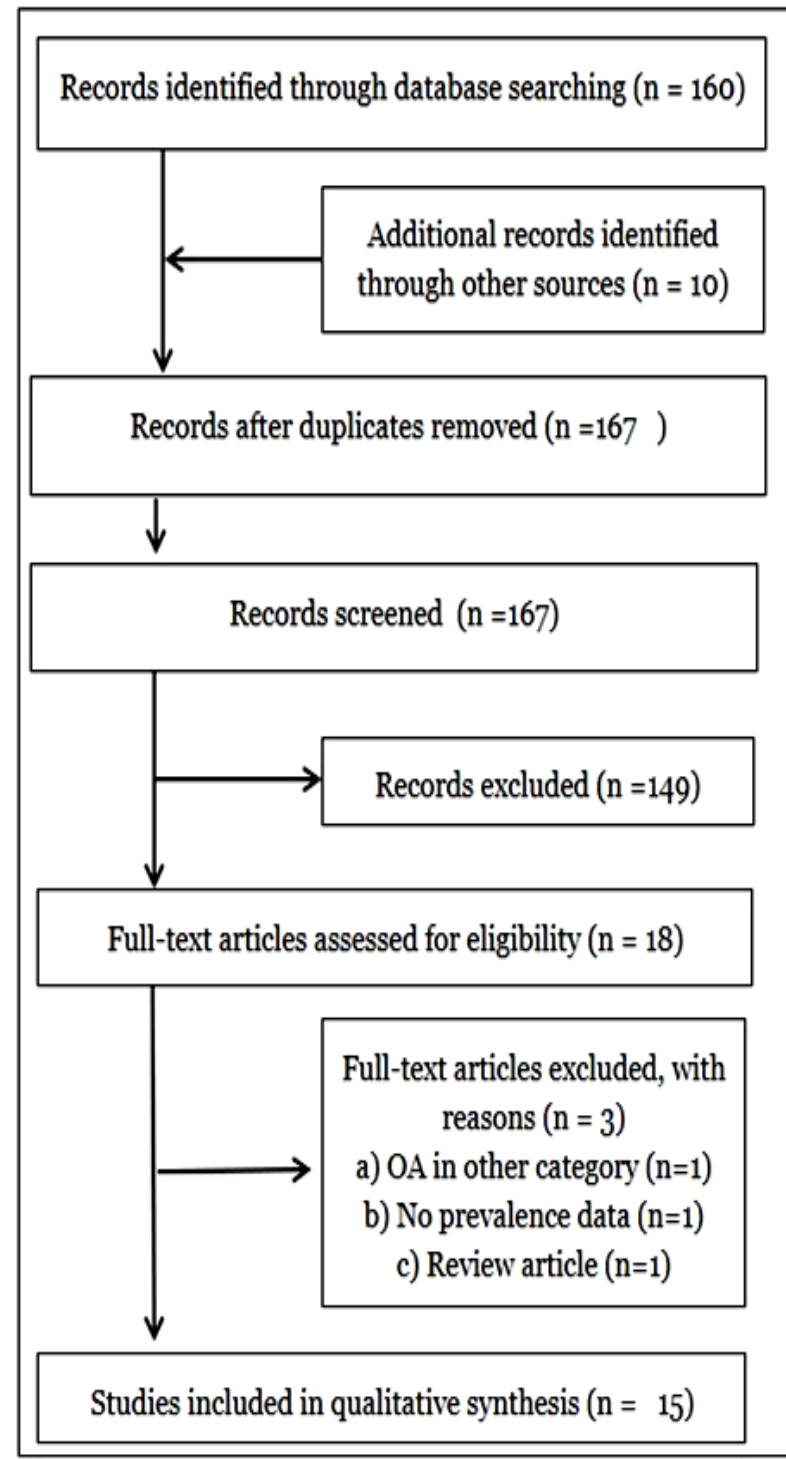

Figure 1. Flow diagram of selection of studies (Moher et al., 2009)

Studies among the Senoi tribe showed that the prevalence of metabolic syndrome was $25.2 \%$ (Ali et al., 2016) and 39.8\% (Zahary et al., 2019). One study among Negrito by Mokhsin et al. (2018) had the prevalence of metabolic syndrome at 
12.0\%. Two studies, among all the Orang Asli tribe, reported a prevalence rate of $17.0 \%$ (Ashari et al., 2016) and 29.6\% (Aghakhanian et al., 2018). They also reported that the prevalence of female with metabolic syndrome was significantly higher compared to male counterparts (Ashari et al., 2016; Aghakhanian et al., 2018) with the weighted mean for gender-adjusted prevalence was 30.0\% and 19.3\% respectively (Ali et al., 2016; Ashari et al., 2016; Aghakhanian et al., 2018; Mokhsin et al., 2018; Zahary et al., 2019).

\section{B. Prevalence of the Components of Metabolic Syndrome}

The prevalence of the cluster of risk factors for metabolic syndrome among the populations varied from one ethnic group to another as well as the measure definition (Table 1).

Abdominal obesity: The prevalence of abdominal obesity (AO) reported in twelve studies. Two studies used waist circumference cut-point values of $102 \mathrm{~cm}$ for males and $88 \mathrm{~cm}$ for females (Yusof et al., 2007; Azuwani et al., 2013). The other ten studies used cut-point values of $90 \mathrm{~cm}$ for males and $80 \mathrm{~cm}$ for females (Haemamalar et al., 2010; Mohamud and Suraiami, 2010; Phipps et al., 2015; Ali et al., 2016; Ashari et al., 2016; Chua et al., 2017; Aghakhanian et al., 2018; Ahmad et al., 2018, Mokhsin et al., 2018; Wong et al., 2018; Zahary et al., 2019). Reported prevalence range from $0.8 \%$ to $37.0 \%$. The weighted mean prevalence was $24.6 \%$.

Abnormal glycemia: Nine studies mentioned the prevalence of abnormal glycaemia (AG) among the Orang Asli population (Mohamud and Suraiami, 2010; Phipps et al., 2015; Ali et al., 2016; Ashari et al., 2016; Aziz et al., 2016; Aghakhanian et al., 2018; Ahmad et al., 2018, Mokhsin et al., 2018; Wong et al., 2018). In these nine studies, the weighted mean prevalence of $\mathrm{AG}$ was $14.0 \%$, with the reported prevalence ranging from $1.5 \%$ to $34.8 \%$.

Hypertension: The weighted mean prevalence of high blood pressure or hypertension (HPT) was found to be $33.7 \%$ in the nine studies that reported on the general prevalence of this component ranging from $21.8 \%$ - 73.6\% (Jinam et al., 2008; Azuwani et al., 2013; Phipps et al., 2015; Ali et al., 2016; Ashari et al., 2016; Aghakhanian et al., 2018; Ahmad et al., 2018; Mokhsin et al., 2018; Wong et al., 2018). In four, the cut-point value for systolic blood pressure was $130 \mathrm{mmHg}$ or more and diastolic blood pressure of $85 \mathrm{mmHg}$ or more (Ali et al., 2016; Ashari et al., 2016; Aghakhanian et al., 2018; Ahmad et al., 2018). Whereas, four studies used a cut-point value of $140 \mathrm{mmHg}$ or more and diastolic blood pressure of $90 \mathrm{mmHg}$ or more (Jinam et al., 2008; Phipps et al., 2015; Mokhsin et al., 2018; Wong et al., 2018). One study did not specify the cut-point values used to categorise HPT (Azuwani et al., 2013).

Dyslipidemia: High triglyceride (TG) and low HDL cholesterol (HDL-C) is the characteristics of dyslipidaemia seen in six studies (Phipps et al., 2015; Ali et al., 2016; Ashari et al., 2016; Aziz et al., 2016; Aghakhanian et al., 2018; Ahmad et al., 2018). Another two studies looked at the components of high TG (Wong et al., 2018) and low HDL-C (Mohamud and Suraiami, 2010). The weighted mean of high TG was 21.5\%, and for low levels of HDL cholesterol, the weighted mean was $41.0 \%$.

\section{DISCUSSION}

This review provides an overall picture of the presence of metabolic syndrome among the Orang Asli population in Malaysia. According to data reviewed, the weighted mean prevalence of metabolic syndrome in the Orang Asli (26.3\%) is as high as the reported study by Rampal et al. in 2012 among the Malaysian population. Ethnic disparities in metabolic syndromes in Malaysia was $35.6 \%$ among Indians, 30.5\% among indigenous Sarawakians, 26.4\% among Malays and 26.2\% among Chinese (Rampal et al., 2012). With the pattern like other ethnicities in Malaysia, there is no doubt that metabolic syndrome is going to be a more challenging public health issue to tackle among the Orang Asli.

This review found that the overall prevalence of metabolic syndrome was higher among Senoi as compared to Negrito. However, in research by Aghakhanian et al. in 2018, metabolic syndrome prevalence was the highest among the Proto-Malays, followed by Negritos and Senois. There was a wide variation in the prevalence of metabolic syndrome amongst different Orang Asli groups, with the highest metabolic syndrome and non-communicable diseases prevalence was observed, particularly among the Orang Asli 
who inhabited urbanised fringe areas (Jinam et al., 2008; Aziz et al., 2016). Risk factors for metabolic syndrome include an unhealthy diet and a sedentary lifestyle. Their adaptation greatly influenced Orang Asli's lifestyle to the environment as their source of food. For the Orang Asli, who mainly live in the fringe, the transition to modernisation leads to a modification in their lifestyle behaviour. Poor diet and physical inactivity were the behavioural risk factors for metabolic syndrome that are preventable (Ashari et al., 2016; Forouzanfar et al., 2016). Physical inactivity prevalence among Orang Asli was as high as the general Malaysian population (Institute for Public Health Malaysia, 2015; Pell et al., 2016; Wong et al., 2018). In a study by Rohin et al. in 2018, 27.6\% of Orang Asli exceed the daily recommended intake of carbohydrate, $19.0 \%$ of daily protein, and $16.0 \%$ of daily fat.

In our review, the mean prevalence of female with metabolic syndrome was higher than male gender, and this differs from studies by Ashari et al. in 2016 and Aghakhanian et al. in 2018. These gender differences are not consistent across the tribe category and geographic locations. However, the finding of a higher prevalence of metabolic syndrome in females in our study was comparable with studies in the general Malaysian population (Mohamud et al., 2011; Rampal et al., 2012). In our results, the most common component of metabolic syndrome was low HDL cholesterol (41.0\%). In studies comparing the prevalence of HDL-C among rural Malay and Orang Asli (Ali et al., 2016; Ahmad et al., 2018), no significant difference found, which suggests the need for monitoring during medical screening among this communities.

The mean prevalence of high blood pressure among the Orang Asli in this review is higher compared to the national survey by the Institute for Public Health Malaysia in 2015. However, abdominal obesity and abnormal glycemia were lower in this review. These groups of Orang Asli often included other groups of ethnicity categories in government health surveys or researches among the Malaysian population. Therefore, the number may not represent their actual health conditions. Reported data on Orang Asli shall be analysed in their category, so targeted intervention can be conducted among these minorities (Mohamud et al., 2011; Institute for Public Health Malaysia; 2015).
Another limitation that makes comparability among studies difficult is the different methods used. For the clinical diagnosis of metabolic syndrome, the cluster of risk factors was the same for any definition used. However, the measurement used for cut-point values may vary across studies depending on the definition used by the author (Alberti et al., 2009). To diagnose metabolic syndrome, the majority (three) of studies used the JIS 2009 criteria (Ali et al., 2016; Ashari et al., 2016; Aghakhanian et al., 2018); one was based on the IDF 2006 criteria (Mokhsin et al., 2018) and one was based on modified NCEP-ATP III (Zahary et al., 2019) (Table 1).

The trend of diseases in the Orang Asli have changed recently from communicable to non-communicable diseases because of the shifts in nutrition and lifestyle habits among the population. Adaptation to modern life has transformed dietary intake, social and lifestyle behaviours, leading to a reduction in their health status not only in Malaysia but also among indigenous people worldwide (Burns and Thomson, 2006; Haemamalar et al., 2008; Jinam et al., 2008).

Due to the high burden of the chronic diseases' management and healthcare cost, studies to describe modifiable environmental and behavioural factors associated with the development of metabolic syndrome is essential. This information is beneficial, especially for potentially modifiable factors such as nutrition and physical inactivity (Forouzanfar et al., 2016; Wong et al., 2018). Since the Orang Asli population is heterogeneous, the information specifying the people who have a higher risk of developing metabolic syndrome should be conducted. This information allows a targeted program and intervention that suit the need of the population. Another critical aspect of metabolic syndrome prevention is their knowledge of diseases (Nor Afiah et al., 2017; Ithnin et al., 2018). Previous studies among Orang Asli reported a low level of knowledge on diseases and their prevention (Al-Adhroey et al., 2010; Ahmad et al., 2013; Nasr et al., 2013). It is, therefore, essential to increase knowledge about metabolic syndrome and its causes, as such knowledge could reduce the prevalence of metabolic syndrome. 


\section{CONCLUSION}

To the best of our knowledge, this is the first systematic review on the prevalence of metabolic syndrome and its components among indigenous Orang Asli populations in Malaysia. Studies among them are limited but starting to increase over the years. The prevalence of metabolic syndrome was as high as the general Malaysian population. Our data also suggest the need for multi-centre studies using current criteria and standardised methods for each ethnic group to make it possible to determine the precise scope of this problem among the Orang Asli populations. Knowledge of diseases may be helpful in the monitoring of metabolic syndrome and could contribute to planning and prevention strategies to combat this condition. High risk of morbidity and mortality of these conditions also increase healthcare costs for the populations and Malaysia government. Hence, all efforts to involve all relevant parties of researchers, communities and government are crucial for disease prevention among these vulnerable populations.

\section{CONFLICT OF INTEREST}

The authors declare that they have no competing interests.

\section{ACKNOWLEDGEMENTS}

This manuscript was prepared as part of the candidature for a PhD with Faculty of Medicine and Health Science, Universiti Sains Islam Malaysia. The authors would like to thank the reviewers for their valuable input and all others who made this study possible.

\section{REFERENCES}

Aghakhanian, F, Wong, C, Tan, JS, Yeo, LF, Ramadas, A, Edo, J, Hoh, BP, Khalid, BA, Phipps, ME 2018, 'Metabolic syndrome and cardiometabolic risk factors among indigenous Malaysians', Public health. https://doi.org/10.1016/j.puhe.2018.10.00

Ahmad B, Khalid BA, Quek KF, Zaini A \& Phipps ME 2013, 'Knowledge of diabetes and lifestyle behaviour amongst indigenous population in Peninsular Malaysia', Medical Journal of Malaysia, vol. 68, no. 4, pp.309.

Ahmad, W, Sugathan, S, Ismail, S, Soe, MM \& Ali, O 2018, 'Cardiovascular risk factors in rural Malays and Aborigines in Perak, Malaysia; an alarming situation', Medical Forum Monthly, vol. 29, no. 12, pp. 24-28.

Al-Adhroey, AH, Nor, ZM, Al-Mekhlafi, HM \& Mahmud, R 2010, 'Opportunities and obstacles to the elimination of malaria from Peninsular Malaysia: knowledge, attitudes and practices on malaria among aboriginal and rural communities,' Malaria Journal, vol. 9, no. 1, pp.137.

Alberti, KG, Zimmet, $\mathrm{P}$ \& Shaw, J 2006, 'Metabolic syndrome-a new worldwide definition. A consensus statement from the international diabetes federation', Diabetic Medicine, vol. 23, no.5, pp.469-480. https://doi.org/10.1111/j.1464-5491.2006.01858.x
Alberti, KG, Eckel, RH, Grundy, SM, Zimmet, PZ, Cleeman, JI, Donato, KA, Fruchart, JC, James, WP, Loria, CM \& Smith Jr, SC 2009, 'Harmonising the metabolic syndrome: a joint interim statement of the international diabetes federation task force on epidemiology and prevention; national heart, lung, and blood institute; American heart association; world heart federation; international atherosclerosis society; and international association for the study of obesity', Circulation, vol. 120, pp.1640-1645. https://doi.org/10.1161/CIRCULATIONAHA.109.192644 Ali, O, Ismail, S, Sugathan, S, Soe, MM, Ahmed, W, Hayati, A, Abidin, Z \& Mutholib, NA 2006. Determination of metabolic syndrome (MetS) among transitional community-comparison between Orang Asli and Malay rural area in Perak. 7th RRPG International Conference and Field Study in Malaysia 2016 (RRPG7), 2016 Universiti Teknologi Malaysia. UTM RAZAK SCHOOL of Engineering and Advanced Technology, Universiti Teknologi Malaysia Kuala Lumpur, 429-433.

Ashari, LS, Mitra, AK, Rahman, TA, Mitra, A, Teh, LK, Salleh, MZ \& Jan Mohamed, HJB 2016, 'Prevalence and risk factors of metabolic syndrome among an endangered tribal population in Malaysia using harmonised IDF criteria', International Journal of Diabetes in Developing 
Countries, vol.36, pp.352-358. https://doi. 10.1007/s13410-016-0487-4

Aziz, TA, Teh, LK, Idris, MH, Bannur, Z, Ashari, LS, Ismail, AI, Ahmad, A, Isa, KM, Nor, FM, Rahman, TH \& Shaari, SA 2016, 'Increased risks of cardiovascular diseases and insulin resistance among the Orang Asli in Peninsular Malaysia', BMC public health, vol. 16, no. 1, p.284.

Azuwani, AR, Noor Khairiah, K, Cheong, YZ, Kok, CC, Aw, NSL, Nadiah Mhd, S \& Abdul Rashid, K 2013, 'Body fat percentage distribution of an Orang Asli group (aborigines) in Cameron Highlands, Malaysia', Malaysian Journal of Nutrition, vol. 19, no.2, pp. 205-214.

Boudreau DM, Malone DC, Raebel MA, Fishman PA, Nichols GA, Feldstein AC, Boscoe AN, Ben-Joseph RH, Magid DJ, Okamoto LJ 2009, 'Health care utilisation and costs by metabolic syndrome risk factors', Metabolic syndrome and related disorders, vol. 74, no.4, pp.305-314. https://doi.org/10.1089/met.2008.007

Burns, J \& Thomson, N 2006, 'Overweight and obesity-a major problem for Indigenous Australians', Health. Vol 1: pp.2.

Chua, EY, Zalilah, MS, Haemamalar, K, Norhasmah, S and Geeta, A 2017, 'Obesity indices predict hypertension among indigenous adults in Krau Wildlife Reserve, Peninsular Malaysia', Journal of Health, Population and Nutrition, vol. 36, no. 1, p.24. https://doi. 10.1186/s41043-017-0102-4

Cornier, M-A, Dabelea, D, Hernandez, TL, Lindstrom, RC, Steig, AJ, Stob, NR, Van Pelt, RE, H. Wang, H \& Eckel, RH 2008, 'The metabolic syndrome', Endocrine Reviews, vol. 29, no. 7, pp. 777-822. https://doi.org/10.1210/er.20080024

Department of Statistics Malaysia 2000, Population distribution and basic demographic characteristics. The 2000 Population and Housing Census of Malaysia. Malaysia Department of Statistics, Putrajaya.

Endicott, K 2015. Malaysia's original people: past, present and future of the Orang Asli. National University of Singapore Press.

Forouzanfar, MH, Afshin, A, Alexander, LT, Anderson, HR, Bhutta, ZA, Biryukov, S, Brauer, M, Burnett, R, Cercy, K, Charlson, FJ \& Cohen AJ 2016, 'Global, regional, and national comparative risk assessment of 79 behavioural, environmental and occupational, and metabolic risks or clusters of risks, 1990-2015: a systematic analysis for the Global Burden of Disease Study 2015', The Lancet, vol. 388, no. 10053, pp.1659-1724. https://doi.org/10.1016/So1406736(16)31679-8
Haemamalar, K, Zalilah, MS \& Neng Azhanie, A 2010, 'Nutritional status of Orang Asli (Che Wong tribe) adults in Krau Wildlife Reserve, Pahang', Malaysian Journal of Nutrition, vol. 16, no.1, pp.55-68.

Ithnin, M, Nor, NA, Nordin, NJ, Effendy, NM, Sahar, MA, Abdullah, KH, Aris, MS, Rani MD 2018, 'Knowledge, attitude, and practice on Non-Communicable Diseases (NCDs) among the adult population in the urban area of Negeri Sembilan, Malaysia' International Journal of Research in Pharmaceutical Sciences, vol. 9 (SPL 2), pp.88-94.

Institute for Public Health 2015, National Health and Morbidity Survey 2015 (NHMS 2015), Vol. II: NonCommunicable Diseases, Risk Factors \& Other Health Problemetabolic syndrome, Malaysia Ministry of Health, Kuala Lumpur.

Lim, KG \& Cheah, WK 2016, 'A review of metabolic syndrome research in Malaysia', Medical Journal of Malaysia, vol.71, pp.20-28.

Masron, T, Masami F \& Ismail N 2013, 'Orang Asli in Peninsular Malaysia: population, spatial distribution and socioeconomic condition', J Ritsumeikan Soc Sci Humanit, vol. 6, pp. 75-115.

Mokhsin, A, Mokhtar, SS, Mohd Ismail, A, M Nor, F, Shaari, SA, Nawawi, H, Yusoff, K, Abdul Rahman, T \& Hoh, BP 2018, 'Observational study of the status of coronary risk biomarkers among Negritos with metabolic syndrome in the east coast of Malaysia', BMJ Open, vol. 8, no. 12, pp.e021580.http://dx.doi.org/10.1136/bmjopen-2018021580

Mohamud, WNW \& Suraiami, M 2010, 'Prevalence of diabetes, impaired fasting glucose and metabolic syndrome among female Orang Asli community in Peninsular Malaysia', International Journal of Diabetes in Developing Countries, vol. 3o, no. 3, pp. 118-122.

Mohamud, WN, Ismail, AA, Sharifuddin, A, Ismail, IS, Musa, KI, Kadir, KA, Kamaruddin, NA, Yaacob, NA, Mustafa, N, Ali O, Harnida, S 2011, 'Prevalence of metabolic syndrome and its risk factors in adult Malaysians: results of a nationwide survey' Diabetes research and clinical practice, vol. $91, \quad$ no. 2, 2 pp.239-245. https://doi.org/10.1016/j.diabres.2010.11.025

Moher D, Liberati A, Tetzlaff J, Altman DG, The PRISMA Group, 2009 'Preferred Reporting Items for Systematic Reviews and Meta-Analyses: The PRISMA Statement.' PLOS Medicine, vol. 6, no. 7, pp. e1000097. 10.1371/journal.pmed.1000097 
Nasr, NA, Al-Mekhlafi, HM, Ahmed, A, Roslan MA \& Bulgiba A 2013, 'Towards an effective control programme of soiltransmitted helminth infections among Orang Asli in rural Malaysia. Part 2: Knowledge, attitude, and practices', Parasites \& Vectors, vol. 6, no. 1, pp.28.

Nor Afiah, MZ, Suriani, I, Rohaiza Aida, HF \& Muhamad Syahir Asyraf, AR 2017, 'Knowledge, attitude and perceptions on second-hand smoke (SHS) exposure among undergraduate students contribute to avoidance of second hand smoke', International Journal of Public Health and Clinical Sciences vol. 4, no. 1, pp. 53-65.

Pell, C, Allotey, P, Evans, N, Hardon, A, Imelda, JD, Soyiri, I \& Reidpath, DD. 2016, 'Coming of age, becoming obese: a cross-sectional analysis of obesity among adolescents and young adults in Malaysia', BMC public health, vol. 16, no.1, pp.1082.

Phipps, ME, Chan, KK, Naidu, R, Mohamad, NW, Hoh, BP, Quek, KF, Ahmad, B, Harnida, SM, Zain, AZ \& Kadir, KA 2015, 'Cardio-metabolic health risks in indigenous populations of Southeast Asia and the influence of urbanisation', BMC Public Health, vol. 15, pp. 47. https://doi.10.1186/s12889-015-1384-3

Rampal S, Mahadeva S, Guallar E, Bulgiba A, Mohamed R, Rahmat R, Arif MT \& Rampal L 2012, 'Ethnic differences in the prevalence of metabolic syndrome: results from a multiethnic population-based survey in Malaysia', PloS one, vol. 7, no. 9, p.p. e46365. https://doi.org/10.1371/journal.pone.0046365

Rohin, MA, Jusoh, AF, Rahim, A, Zahary, MN, Aziz, AA, Him, NA, Yahaya, R, Ridzwan, N, Jumli, MN \& Harun S 2018, 'Nutritional Status of the Temiar Orang Asli Community in Kuala Betis, Gua Musang, Kelantan', Pakistan Journal of Nutrition, vol. 17, no. 7, pp.311-318.

Wong CM, Faiz D, Diana Safraa S, Raja Mohd Azim RH, Siti Zubaidah AR 2018, 'Prevalence and Modifiable Risk Factors of Non-Communicable Diseases among Jakun Orang Asli at Tasik Chini, Pekan, Pahang', The International Medical Journal of Malaysia, vol.17, pp. 316.

Yusof, HM, Ching, TS, Ibrahim, R \& Lola, S 2007, 'Anthropometric indices and lifestyle practices of the indigenous Orang Asli adults in Lembah Belum, Grik of Peninsular Malaysia', Asia Pacific journal of clinical nutrition, vol.16, no.1, pp. 49-55. https://doi.10.6133/apjen.2007.16.1.07.

Zahary, MN, Harun, NS, Yahaya, R, Nik Him, NAS, Rohin, MAK, Ridzwan, NH, Jumli, MN \& Wan Jusoh, AF 2019,
'Serum adiponectin and resistin: Correlation with metabolic syndrome and its associated criteria among temiar subtribe in Malaysia', Diabetes and Metabolic Syndrome: Clinical Research and Reviews, vol. 13, pp.2015-2019. https://doi.org/10.1016/j.dsx.2019.04.048. 
ASM Science Journal, Volume 15, 2021

Table 1. Cross-sectional studies of the prevalence of metabolic syndrome among Orang Asli populations included in the present review

\begin{tabular}{|c|c|c|c|c|c|c|c|c|}
\hline Author & $\begin{array}{l}\text { Study } \\
\text { period }\end{array}$ & Population study & City, State & Cut-Points value & $\begin{array}{l}\text { Metabolic } \\
\text { syndrome } \\
\text { definition }\end{array}$ & $\begin{array}{l}\text { Overall } \\
\text { prevalence } \\
\text { MetS(\%) }\end{array}$ & $\begin{array}{l}\text { Prevalence of } \\
\text { individual } \\
\text { components of } \\
\text { MetS (\%) }\end{array}$ & Associations* \\
\hline $\begin{array}{l}\text { Yusof et al., } \\
2007\end{array}$ & 2002 & $\begin{array}{l}138 \text { adults, } \\
\geq 16 \text { years old } \\
\mathrm{M} \text { and } \mathrm{F} \\
58.7 \% \text { Negrito, } \\
\text { 41.3\% Senoi }\end{array}$ & $\begin{array}{l}\text { Lembah Belum, } \\
\text { Perak }\end{array}$ & $\begin{array}{l}\text { AO: WC; } M>102 \mathrm{~cm}, \mathrm{~F}>88 \mathrm{~cm} \\
\text { High G: - } \\
\text { High TG: - } \\
\text { Low HDL-C: - } \\
\text { HPT: - }\end{array}$ & - & - & $\begin{array}{l}\text { AO: o.8 } \\
\text { High G:- } \\
\text { High TG: - } \\
\text { Low HDL-C: - } \\
\text { HPT: - }\end{array}$ & - \\
\hline $\begin{array}{l}\text { Jinam, et al., } \\
2008\end{array}$ & - & $\begin{array}{l}129 \text { adults, } \\
\geq 20 \text { years old } \\
\mathrm{M} \text { and } \mathrm{F} \\
38.4 \% \text { Proto-Malay, } \\
61.6 \% \text { Negrito }\end{array}$ & $\begin{array}{l}\text { Kuala Pilah } \\
\text { and Jelebu, Negeri } \\
\text { Sembilan, Grik, } \\
\text { Perak Baling, Kedah }\end{array}$ & $\begin{array}{l}\text { AO: - } \\
\text { High G: - } \\
\text { High TG: - } \\
\text { Low HDL-C: - } \\
\text { HPT: } \geq 140 / 90 \mathrm{mmHg}\end{array}$ & - & - & $\begin{array}{l}\text { AO: - } \\
\text { High G:- } \\
\text { High TG: - } \\
\text { Low HDL-C: - } \\
\text { HPT: } 49.6\end{array}$ & - \\
\hline $\begin{array}{l}\text { Haemamalar } \\
\text { et al., } 2010\end{array}$ & - & $\begin{array}{l}57 \text { adults, } \\
\geq 18 \text { years old } \\
\mathrm{M} \text { and F } \\
100 \% \text { Senoi }\end{array}$ & $\begin{array}{ll}\text { Krau } & \text { Wildlife } \\
\text { Reserve, } & \\
\text { Pahang } & \end{array}$ & $\begin{array}{l}\text { AO: WC; } M>90 \mathrm{~cm}, \mathrm{~F}>80 \mathrm{~cm} \\
\text { High G: - } \\
\text { High TG: - } \\
\text { Low HDL-C: - } \\
\text { HPT: - }\end{array}$ & - & - & $\begin{array}{l}\text { AO: } 10.5 \\
\text { High G:- } \\
\text { High TG: - } \\
\text { Low HDL-C: - } \\
\text { HPT: - }\end{array}$ & - \\
\hline $\begin{array}{l}\text { Mohamud \& } \\
\text { Suraiami, } \\
2010\end{array}$ & - & $\begin{array}{l}119 \text { adults, } \\
\geq 18 \text { years old } \\
\text { F only } \\
100 \% \text { Proto-Malay }\end{array}$ & $\begin{array}{l}\text { Hulu Selangor, } \\
\text { Selangor }\end{array}$ & $\begin{array}{l}\text { AO: } W C ; F>80 \mathrm{~cm} \\
\text { High G: } F B G \geq 5.6 \mathrm{mmol} / \mathrm{L} \\
\text { High TG: } \geq 1.7 \mathrm{mmol} / \mathrm{L} \\
\text { Low HDL-C: } \leq 1.29 \mathrm{mmol} / \mathrm{L} \\
\text { HPT: - }\end{array}$ & - & - & $\begin{array}{l}\text { AO: } 19.6 \\
\text { High G: } 34.8 \\
\text { High TG: } 9.8 \\
\text { Low HDL-C: } 44.6 \\
\text { HPT: - }\end{array}$ & - \\
\hline $\begin{array}{l}\text { Azuwani et al., } \\
2013\end{array}$ & - & $\begin{array}{l}138 \text { adults, } \\
\geq 18 \text { years old } \\
\mathrm{M} \text { and } \mathrm{F} \\
100 \% \text { Senoi }\end{array}$ & $\begin{array}{l}\text { Cameroon } \\
\text { Highland, Perak }\end{array}$ & $\begin{array}{l}\text { AO: WC; } M>102 \mathrm{~cm}, \mathrm{~F}>88 \mathrm{~cm} \\
\text { High G: - } \\
\text { High TG: - } \\
\text { Low HDL-C: - } \\
\text { HPT: N/S }\end{array}$ & - & - & $\begin{array}{l}\text { AO: } 13.0 \\
\text { High G: - } \\
\text { High TG: - } \\
\text { Low HDL-C: - } \\
\text { HPT: } 42.0\end{array}$ & - \\
\hline $\begin{array}{l}\text { Phipps et al., } \\
2015\end{array}$ & - & $\begin{array}{l}636 \text { adults, } \\
\geq 18 \text { years old } \\
\text { M and F } \\
\text { 50.8\% Proto-Malay, } \\
\text { 18.2\% Senoi, } \\
\text { 31.0\% Negrito }\end{array}$ & $\begin{array}{l}\text { Pekan, Pahang; } \\
\text { Johor Bahru, Johor; } \\
\text { Cameron } \\
\text { Highlands, Perak; } \\
\text { Kuala Langat, } \\
\text { Selangor; Hulu } \\
\text { Perak, Perak; Gua } \\
\text { Musang, Kelantan }\end{array}$ & $\begin{array}{l}\text { AO: WC; } \mathrm{M}>90 \mathrm{~cm}, \mathrm{~F}>80 \mathrm{~cm} \\
\text { High G: } \mathrm{FBG} \geq 6.1 \mathrm{mmol} / \mathrm{L} \\
\text { High TG: } \geq 1.7 \mathrm{mmol} / \mathrm{L} \\
\text { Low HDL-C: } \leq \mathrm{M}<1.0 \mathrm{mmol} / \mathrm{L}, \mathrm{F} \\
<1.3 \mathrm{mmol} / \mathrm{L} \\
\text { HPT: } \geq 140 / 90 \mathrm{mmHg}\end{array}$ & - & - & $\begin{array}{l}\text { AO: } 34.8 \\
\text { High G: } 7.4 \\
\text { High TG: } 23.9 \\
\text { Low HDL-C: } 45.8 \\
\text { HPT: } 29.6\end{array}$ & - \\
\hline Ali et al., 2016 & - & $\begin{array}{l}135 \text { adults, } \\
\geq 18 \text { years old } \\
\mathrm{M} \text { and } \mathrm{F} \\
100 \% \text { Senoi }\end{array}$ & $\begin{array}{l}\text { Batang Padang and } \\
\text { Hulu Perak, Perak }\end{array}$ & $\begin{array}{l}\text { AO: } W C ; M>90 \mathrm{~cm}, \mathrm{~F}>80 \mathrm{~cm} \\
\text { High } \mathrm{G}: \mathrm{FBG} \geq 5.6 \mathrm{mmol} / \mathrm{L} \text { or on } \\
\text { treatment }\end{array}$ & JIS, 2009 & 25.2 & $\begin{array}{l}\text { AO: } 37.0 \\
\text { High G: } 4.4 \\
\text { High TG: } 22.2 \\
\text { Low HDL-C: } 86.7\end{array}$ & - \\
\hline
\end{tabular}




\begin{tabular}{|c|c|c|c|c|c|c|c|c|}
\hline & & & & $\begin{array}{l}\text { High TG: } \geq 1.7 \mathrm{mmol} / \mathrm{L} \text { or on } \\
\text { treatment } \\
\text { Low HDL-C: } \leq \mathrm{M}<1.03 \mathrm{mmol} / \mathrm{L} \text {, } \\
\mathrm{F}<1.29 \mathrm{mmol} / \mathrm{L} \text { or on treatment } \\
\text { HPT: } \geq 130 / 85 \mathrm{mmHg}\end{array}$ & & & HPT: 34.8 & \\
\hline $\begin{array}{l}\text { Ashari et al., } \\
2016\end{array}$ & $\begin{array}{l}2011- \\
2013\end{array}$ & $\begin{array}{l}159 \text { adults, } \\
\geq 18 \text { years old } \\
\text { M and F } \\
\text { 6.9\% Proto-Malay, } \\
\text { 43.4\% Senoi, } \\
\text { 49.7\% Negrito }\end{array}$ & $\begin{array}{l}\text { Kota tinggi, Johor; } \\
\text { Kuala Lipis and } \\
\text { Lanchang, Perak; } \\
\text { Baling, Kedah; } \\
\text { Lanchang, Perak }\end{array}$ & $\begin{array}{l}\text { AO: WC; } \mathrm{M}>90 \mathrm{~cm}, \mathrm{~F}>80 \mathrm{~cm} \\
\text { High G: } \mathrm{FBG} \geq 5.6 \mathrm{mmol} / \mathrm{L} \\
\text { High TG: } \geq 1.7 \mathrm{mmol} / \mathrm{L} \\
\text { Low HDL-C: }<1.0 \mathrm{mmol} / \mathrm{L} \\
\text { HPT: } \geq 130 / 85 \mathrm{mmHg}\end{array}$ & JIS, 2009 & 17.0 & $\begin{array}{l}\text { AO: } 37.0 \\
\text { High G: } 4.4 \\
\text { High TG: } 22.2 \\
\text { Low HDL-C: } 86.7 \\
\text { HPT: } 34.8\end{array}$ & $\begin{array}{l}\text { Chi-square test: } \\
\text { Females had a } \\
\text { significantly higher } \\
\text { prevalence of MetS } \\
\text { (23.8 vs. } 5.2 \%, \mathrm{P}= \\
\text { O.002) }\end{array}$ \\
\hline $\begin{array}{l}\text { Aziz et al., } \\
2016\end{array}$ & - & $\begin{array}{l}85 \text { adults, } \\
\geq 18 \text { years old } \\
\text { M and F } \\
\text { 5.8\% Proto-Malay, } \\
\text { 37.2\% Senoi, } \\
\text { 57.1\% Negrito }\end{array}$ & $\begin{array}{l}\text { Pahang, Kelantan, } \\
\text { Perak, Kedah, Johor }\end{array}$ & $\begin{array}{l}\text { AO: WC; }- \\
\text { High G: } \mathrm{FBG} \geq 6.1 \mathrm{mmol} / \mathrm{L} \\
\text { High TG: } \geq 1.7 \mathrm{mmol} / \mathrm{L} \\
\text { Low HDL-C: }<1.0 \mathrm{mmol} / \mathrm{L} \\
\text { HPT: - }\end{array}$ & - & - & $\begin{array}{l}\text { AO: - } \\
\text { High G: } 24 \cdot 7 \\
\text { High TG: } 20.0 \\
\text { Low HDL-C: } 34.1 \\
\text { HPT: } 25.9\end{array}$ & - \\
\hline $\begin{array}{l}\text { Chua et al., } \\
2017\end{array}$ & - & $\begin{array}{l}482 \text { adults, } \\
\geq 18 \text { years old } \\
\mathrm{M} \text { and } \mathrm{F} \\
27.4 \% \text { Proto-Malay, } \\
\text { 72.6\% Senoi }\end{array}$ & $\begin{array}{l}\text { Krau Wildlife } \\
\text { Reserve, Pahang }\end{array}$ & $\begin{array}{l}\text { AO: } M>90 \mathrm{~cm}, \mathrm{~F}>80 \mathrm{~cm} \\
\text { High G: - } \\
\text { High TG: - } \\
\text { Low HDL-C: - } \\
\text { HPT: - }\end{array}$ & - & - & $\begin{array}{l}\text { AO: } 22.4 \\
\text { High G: - } \\
\text { High TG: - } \\
\text { Low HDL-C: - } \\
\text { HPT: - }\end{array}$ & - \\
\hline $\begin{array}{l}\text { Aghakhanian } \\
\text { et al., } 2018\end{array}$ & $\begin{array}{l}2010- \\
2016\end{array}$ & $\begin{array}{l}629 \text { adults, } \\
\geq 18 \text { years old } \\
\text { M and F } \\
\text { 50.1\% Proto-Malay, } \\
23.7 \% \text { Senoi, } \\
26.3 \% \text { Negrito }\end{array}$ & $\begin{array}{l}\text { Pahang, Johor } \\
\text { Selangor, Perak } \\
\text { Perak, Kelantan }\end{array}$ & $\begin{array}{l}\text { AO: } \mathrm{WC} ; \mathrm{M}>90 \mathrm{~cm}, \mathrm{~F}>80 \mathrm{~cm} \\
\text { High G: } \mathrm{FBG} \geq 5.6 \mathrm{mmol} / \mathrm{L} \text { or on } \\
\text { treatment } \\
\text { High TG: } \geq 1.7 \mathrm{mmol} / \mathrm{L} \\
\text { Low HDL-C: } \mathrm{M}<1.0 \mathrm{mmol} / \mathrm{L}, \mathrm{F} \\
<1.3 \mathrm{mmol} / \mathrm{L} \\
\text { HPT: } \geq 130 / 85 \mathrm{mmHg} \text { or on } \\
\text { treatment }\end{array}$ & JIS, 2009 & 29.6 & $\begin{array}{l}\text { AO: } 21.5 \\
\text { High G: } 20.0 \\
\text { High TG: } 19.1 \\
\text { Low HDL-C: } 17.6 \\
\text { HPT: } 21.8\end{array}$ & $\begin{array}{l}\text { Chi-square test: } \\
\text { Females had a } \\
\text { significantly higher } \\
\text { prevalence of MetS, } \\
\text { (35.25\% vs } 21.95 \%, \mathrm{P} \\
\text { < o.001) compared to } \\
\text { males. }\end{array}$ \\
\hline $\begin{array}{l}\text { Ahmad et al., } \\
2018\end{array}$ & 2013 & $\begin{array}{l}133 \text { adults, } \\
\geq 18 \text { years old } \\
\mathrm{M} \text { and } \mathrm{F} \\
100 \% \text { Senoi }\end{array}$ & $\begin{array}{l}\text { Batang Padang and } \\
\text { Hulu Perak, Perak }\end{array}$ & $\begin{array}{l}\text { AO: WC; } \mathrm{M}>90 \mathrm{~cm}, \mathrm{~F}>80 \mathrm{~cm} \\
\text { High G: } \mathrm{FBG} \geq 5.6 \mathrm{mmol} / \mathrm{L} \text { or on } \\
\text { treatment } \\
\text { High TG: } \geq 1.7 \mathrm{mmol} / \mathrm{L} \\
\text { Low HDL-C:M }<1.0 \mathrm{mmol} / \mathrm{L}, \mathrm{F} \\
<1.3 \mathrm{mmol} / \mathrm{L} \text { or on treatment } \\
\text { HPT: } \geq 130 / 85 \mathrm{mmHg}\end{array}$ & - & - & $\begin{array}{l}\text { AO: } 26.9 \\
\text { High G: } 3.8 \\
\text { High TG: } 33.7 \\
\text { Low HDL-C: } 62.5 \\
\text { HPT: } 39.4\end{array}$ & - \\
\hline $\begin{array}{l}\text { Mokhsin et al., } \\
2018\end{array}$ & - & $\begin{array}{l}150 \text { adults, } \\
\geq 18 \text { years old } \\
\mathrm{M} \text { and } \mathrm{F} \\
100 \% \text { Negrito }\end{array}$ & $\begin{array}{l}\text { Gua } \\
\text { Musang, Kelantan }\end{array}$ & $\begin{array}{l}\text { AO: } W C ; M>90 \mathrm{~cm}, \mathrm{~F}>80 \mathrm{~cm} \\
\text { High G: } \mathrm{FBG} \geq 5.6 \mathrm{mmol} / \mathrm{L} \\
\text { High TG: } \geq 1.7 \mathrm{mmol} / \mathrm{L} \text { or on } \\
\text { treatment }\end{array}$ & IDF, 2006 & 12.0 & $\begin{array}{l}\text { AO: } 14.0 \\
\text { High G: } 1.5 \\
\text { High TG: - } \\
\text { Low HDL-C: - } \\
\text { HPT: } 57.2\end{array}$ & - \\
\hline
\end{tabular}


Low HDL-C:M <1.ommol/L, F $<1.3 \mathrm{mmol} / \mathrm{L}$ or on treatment HPT: $\geq 130 / 85 \mathrm{mmHg}$

$\begin{array}{ll}\text { Wong et al., } \quad 2015 \quad & 72 \text { adults, } \\ & \geq 18 \text { years old } \\ & \text { M and F } \\ & 100 \% \text { Proto-Malay }\end{array}$

Zahary et al., $\quad-\quad 123$ adults,
2019
$\quad 18$ years old
M and F
$100 \%$ Senoi

Tasik Chini, Pahang AO: WC; $\mathrm{M}>90 \mathrm{~cm}, \mathrm{~F}>80 \mathrm{~cm}$

High G: $F B G \geq 5.6 \mathrm{mmol} / \mathrm{L} \mathrm{L}$

$\mathrm{RBG} \geq 11.1 \mathrm{mmol} / \mathrm{L}$ or on

treatment

High TG: $\geq 1.7 \mathrm{mmol} / \mathrm{L}$

Low HDL-C: -

HPT: $\geq 140 / 90 \mathrm{mmHg}$
Gua
Musang,
AO: WC; $\mathrm{M}>90 \mathrm{~cm}, \mathrm{~F}>80 \mathrm{~cm}$
High G: FBG $\geq 5.6 \mathrm{mmol} / \mathrm{L}$ or on
treatment
High TG: $\geq 1.7 \mathrm{mmol} / \mathrm{L}$ or on
treatment
Low HDL-C: $\leq \mathrm{M}<1.03 \mathrm{mmol} / \mathrm{L}$,
$\mathrm{F}<1.29 \mathrm{mmol} / \mathrm{L}$ or on treatment
HPT: $\geq 130 / 85 \mathrm{mmHg}$

$\begin{array}{lll}\text { modified } & 39.8 & \text { AO: - } \\ \text { NCEP-ATP } & & \text { High G: - } \\ \text { III, 2006 } & & \text { High TG: - } \\ & \text { Low HDL-C: - } \\ & \text { HPT: - }\end{array}$
AO: 33.3
High G: 25.0
High TG: 6.9
Low HDL-C: -
HPT: 73.6

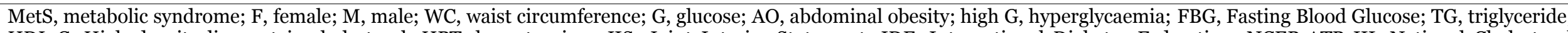

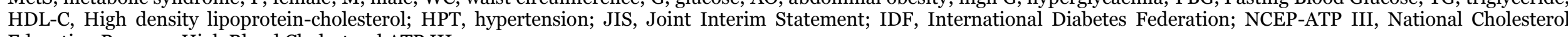
Education Program High Blood Cholesterol ATP III
\end{abstract}

*Only statistically significant associations are shown $(\mathrm{P}<0.05)$. 